\title{
A Comparative Study of Zamindari, Raiyatwari and Mahalwari Land Revenue Settlements: The Colonial Mechanisms of Surplus Extraction in $19^{\text {th }}$ Century British India
}

\author{
Dr. Md Hamid Husain \\ Guest Faculty, Zakir Husain Delhi College, University of Delhi, India \\ Firoj High Sarwar \\ Research Scholar, Department of History (CAS), AMU, Aligarh, India
}

\begin{abstract}
As a colonial mechanism of exploitation the British under East India Company invented and experimented different land revenue settlements in colonized India. Historically, this becomes a major issue of discussion among the scholars in the context of exploitation versus progressive mission in British India. Here, in this paper an attempt has been made to analyze and to interpret the prototype, methods, magnitudes, and farreaching effects of the three major (Zamindari, Raiytwari and Mahalwari) land revenue settlements in a comparative way. And eventually this paper has tried to show the cause-effects relationship of different modes of revenue assessments, which in turn, how it facilitated Englishmen to provide huge economic vertebrae to the Imperial Home Country, and how it succors in altering Indian traditional society and economic set up.
\end{abstract}

Keywords: Diwani (revenue collection right), Mahal (estate), Potta (lease), Raiyat (peasant), Zamindar (land lord)

\section{Introduction}

As agriculture has been the most important economic activity of the Indian people for many centuries and it is the main source of income. Naturally, land revenue management and administration needs a proper care to handle because it was the most important source of income for the state too. The establishment of East India Company worked as the tool of colonial plunder which operated through monopoly of trade and realization of land revenue. To annihilate the traditional Asiatic mode of production, the British Moneyocracy had converted India into its landed estates and hastens the process of commercial revolution in India. ${ }^{1}$ They unleashed far reaching changes in Indian agrarian structure in order to maximize extraction which slowed down the country's progressive development and raised the burden on the Indian peasantry.

To consolidate political sword, the English East India Company inherited the institutional form of agrarian system from the Mughal. They super-imposed a system over the existing land settlement pattern in tune with British customs and laws relating to land. Accordingly, government sponsored cooperative movement through different land revenue experiments and brought several changes in land tenure, property relation, agrarian productivity, food supply, marketing, agriculture indebtedness and cultivated land in British-India. ${ }^{2}$ Gradually, all these changes transformed Indian economic history from mercantile phase to finance capitalism.

After gaining full control over Bengal in 1765 (year of Diwani rights acquisition), Company follow traditional land assessment system in the starting but gradually modified the existing land settlement from time to time to collect maximum possible land revenue which was a need of colonial administration. ${ }^{3}$ They initiated auction based farming system as the first experiment in 1772, where land revenue collection rights had been allotted on contract basis. This farming system slowly developed into three major land settlements, viz., Zamindari in Bengal, Raiyatwari in Madras and Bombay, and Mahalwari in North Western Provinces which exposed the 'colonial character of British rule' and became the basis of primary accumulation of capital. The basic characteristic of each system was the attempt to incorporate elements of the preceding agrarian structure. The existing systems under the colonial policy produced widely different local results and hybrid forms. ${ }^{4}$

Indian economy had been colonized on basis of two important things, first, the mode of production specially the system of surplus extraction existing on the eve of the British conquests. Other was the nature of the British Imperialism which transferred the Indian economy under the impact of the industrial revolution. ${ }^{5}$

\footnotetext{
${ }^{1}$ Karl Marx, The Future Result of British in India, New York Daily Tribune, June 1853. No.3840, in Marx and Angles; On Colonialism ,Foreign Language Publishing House, Moscow, 1960, p. 85

${ }^{2}$ A. R Desai, Social Background of Indian Nationalism, Popular Prakashan, Bombay, 1948, p. 41-47

${ }^{3}$ Sekhar Bandyopadhayay; From Plassey to Partition: A History of Modern India, Orient Longman, New Delhi, 2004, p. 82

${ }^{4}$ Romesh C. Dutt, The Economic History of India: In the Victorian Age, Vol -II, Ministry of information and Broadcasting, govt. of India, New Delhi, 1963, p. xiiv (Preface Section)

${ }^{5}$ Irfan Habib; Essays in Indian History, Tulika Books, New Delhi, 1995, p.297
} 
A Comparative Study Of Zamindari, Raiyatwari And Mahalwari Land Revenue Settlements: The

Basically, the comparison of all the settlement was made on the basis of its territorial boundary, its assessment procedures and its impact on society and social order. The immediate consequence of implementation of the Permanent Settlement was both sudden and very dramatic, and one which nobody had apparently foreseen. By ensuring that Zamindars' (Land Lord) lands were held in perpetuity and with a fixed tax burden, they became desirable commodities. In addition, the government tax demand was inflexible and the British East India Company's collectors refused to make allowances for times of drought, flood or other natural disaster. The tax demand was higher than that in England at the time. As a result, many Zamindars immediately fell into arrears. The Company's policy of auction of any Zamindari lands deemed to be in arrears created a market for land which previously did not exist. Many of the new purchasers of this land were Indian officials within the East India Company's government. These bureaucrats were ideally placed to purchase lands which they knew to be under assessed, and therefore profitable. Historian Bernhard Cohn and others have argued that the Permanent Settlement led firstly to a commercialization of land which previously did not exist in Bengal. And secondly, as a consequence of this, it led to a change in the social background of the ruling class from "lineages and local chiefs" to "under civil servants and their descendants, and to merchants and bankers". ${ }^{6}$ The new landlords were different in their outlook; "often they were absentee landlords who managed their land through managers and who had little attachment to their land".

The Company hoped that the Zamindari class would not only be a revenue-generating instrument but serve as intermediaries for the political dominance of their rule, preserving local custom and protecting rural life from the possibly rapacious influences of its own representatives. However, this worked in both ways; Zamindars became a conservative interest group. There was a tendency of Company officials and Indian landlords to force their tenants into plantation-style farming of cash crops like indigo and cotton rather than rice and wheat. This was a cause of many of the worst famines of the nineteenth century. In addition, Zamindars eventually became absentee landlords, with all that implies for neglect of investment on the land. Once the salient features of the Settlement were reproduced all over India, the political structure was altered forever. The limitation of the state demand enabled the Zamindars to accumulate capital which expended in fostering agricultural enterprise, industries, public and private institutions, and in supporting the poor in the time of distress. The capital accumulated by the Zamindars was widely distributed and promoted well being of all classes. $^{7}$

The Raiyatwari system instituted in some parts of British India by 1820 was one of the two main systems used to collect revenues from the cultivators directly. However, the amount of revenues included undifferentiated land taxes and rents, collected simultaneously. Where the land revenue was imposed directly on the Raiyts - the individual cultivators who actually worked the land - the system of assessment was known as Raiytwari. Where the land revenue was imposed indirectly - through agreements made with Zamindars - the system of assessment was known as Zamindari. In Bombay, Madras, Assam and Burma the Zamindar usually did not have a position of middleman between the government and the farmer. ${ }^{8}$

John Stuart Mill in 1857 explained the Raiyatwari land tenure system as 'the System where every registered holder of land is recognized as its proprietor, and pays rent directly to the Government'. He is at liberty to sublet his property, or to transfer it by gift, sale, or mortgage. He cannot be ejected by Government so long as he pays the fixed assessment, and has the option annually of increasing or diminishing his holding, or of entirely abandoning it. In unfavorable seasons remissions of assessment are granted for entire or partial loss of produce. The assessment is fixed in money, and does not vary from year to year, in those cases where water is drawn from a Government source of irrigation to convert dry land into wet, or into two-crop land, when an extra rent is paid to Government for the water so appropriated; nor is any addition made to the assessment for improvements effected at the Raiyat's own expense. The peasants under this system is virtually a Proprietor on a simple and perfect title, and has all the benefits of a perpetual lease without its responsibilities, inasmuch as he can at any time throw up his lands, but cannot be ejected so long as he pays his dues; he receives assistance in difficult seasons, and is irresponsible for the payment of his neighbors. ${ }^{9}$

The Annual Settlements under Raiyatwari are often misunderstood, and it is necessary to explain that they are rendered necessary by the right accorded to the Raiyat of diminishing or extending his cultivation from year to year. Their object is to determine how much of the assessment due on his holding the Raiyat shall pay, and not to reassess the land. In these cases where no change occurs in the Raiyats holding a fresh Potta or lease is not issued, and such parties are in no way affected by the Annual Settlement, which they are not required to attend. John Stuart Mill, Examiner of the India Office, "Return to an Order of the House of Commons (June 97),

\footnotetext{
${ }^{6}$ Bandopadhayaya, S., op. cit. pp. $84-87$

${ }^{7}$ From the private secretary to his Excellency the Viceroy and Governor General in India, Dated $14^{\text {th }}$ May 1900 , Transfer for Disposal, A

Memorial from Mr. R. C., Dutt Regarding Land Settlement, in Bengal Proceedings No. 22, Serial No. 4, p. 21

${ }^{8}$ Henry Cotton; India in Transition, B. R. Publishing Corporation, Delhi, 1885, p. 80-81

${ }^{9}$ R. C. Dutt's Letter to Lord Curzon on the subject of Land Revenue Settlements in Madras, dated $20^{\text {th }}$ February 1900, Proceedings No. 20, Serial No. 2. p. 2
} 
A Comparative Study Of Zamindari, Raiyatwari And Mahalwari Land Revenue Settlements: The showing under what tenures, and subject to what Land Tax, lands are held under the several Presidencies of India. ${ }^{10}$

The Raiyatwari system is associated with the name of Sir Thomas Munro, who was appointed Governor of Madras in May 1820. Subsequently, this system was extended to the Mumbai area under the supervision of Thomas Reid. Munro gradually reduced the rate of taxation from one half to one third of the gross produce, even then an excessive tax. The levy was not based on actual revenues from the produce of the land, but instead on an estimate of the potential of the soil; in some cases more than $50 \%$ of the gross revenue was demanded. ${ }^{11}$ Half the gross produce of the soil is demanded by Government, and this, which is nearly the average rate wherever there is not a Permanent Settlement, is sadly too much to leave an adequate provision for the present". ${ }^{12}$

Basically, the Raiyatwari system was more pragmatic than doctrinal. By that time the local chiefs were mostly eliminated or reduced to insignificance. The contact of the administration with each individual farmer, implied in the Raiyatwari system appeared more conducive to the interest of the state, which could itself asses the cultivated area and the income of the tax payer, and which could itself carry out the collection of taxes. This system also the advantage for the peasant would be liberated from the oppressive domination of a big land owner. Lastly, even though prejudicial to the landed gentry where it existed, this system perturbed less , apparently at least, the customs and social balances of the rural world. ${ }^{13}$

The core of the utilitarian philosophy of political economy developed by Ricardo professed a scientific foundation for the land revenue system. James Mill played a master role in the institution of new land revenue system. He was from 1819 until1830 immediately responsible for drafting the revenue dispatches to India for following liberal land revenue assessment. Utilitarians hopes of inaugurating a comparative society, based on individual rights in the soil, depended as much upon the revenue assessment, and the registration of landholdings which accompanied it, as upon the superstructure of judicial cods and establishment. ${ }^{14}$ In this context Stocks has argued, in a well known study that the ideological distaste for landlordism, born of utilitarian philosophy, was a major force behind the development of Raiyatwari and Mahalwari settlements, with the implication that policy may have ruined traditionally powerful landlord groups. Possible example here are the 'talukdars' of northern India, whose previous control over the revenue settlements of many villages was frequently set aside by Mahalwari arrangements. In the mind of such as Munro and Wingate- the leading figures behind respectively the Madras and Bombay systems- utilitarian dislike of landlordism was doubtless reinforced by political experience of regions where cultivating peasants typically controlled the land. ${ }^{15}$.Without any doubt, the ideas in vogue in Great Britain at the time also played certain role in choosing the pattern of settlement. They echoed in effect the growing intellectual influence of utilitarian philosopher like James Mill, Bentham, Stuart Mil etc., whose aversion to landlordism was markedly asserted. Perhaps it also reflected at the dawn of the European Romanticism, the idealization of rustic values that had currency in the Home country. ${ }^{16}$

The Mahalwari system was introduced by 1822 with the estate or 'mahals' proprietary bodies where lands belong jointly to the village community technically called the body of co-shares. The body of co-shares is jointly responsible for the payment of land revenue though individual responsibility was not left out completely. The question of introducing a settlement of land revenue in the ceded and conquered provinces came to be the fore by the coming of $19^{\text {th }}$ century. However, this system was started only by passing the Regulation VII of 1822 which the practical implication of Mackenzie's minute of 1819. The system had been broke down because of the excessive state demand and rigidity in its working and collection of land revenue. In a typically Mahalwari village, the co-sharers are actually the cultivators. According to J. S. Mill, 'the peasant proprietors compound with the state for a fixed period. The proprietors did not engage themselves individually with the government, but by villages". ${ }^{17}$

When William Bentinck assumed the governorship of India, he made a thorough review of the scheme of 1822 by which Mahalwari system had been introduced. The government of Bentinck came to the conclusion that the Regulation of 1822 had caused a widespread misery. After a prolonged consultation and discussion he passed the Regulation IX of 1833. This regulation made the terms and conditions of the Mahalwari system more flexible. The new scheme worked under the supervision of Martins Bird. The new system started a new scheme

\footnotetext{
${ }^{10}$ Dutt, R. C., The Economic History of India: Under Early British Rule, Vol. II, Routledge \& Kegan Ltd., London, 1882, First Indian Edition 1960, Publication division, Ministry of Information and Broadcasting, Government of India Press, New Delhi, Reprinted 1963. pp. 93-4

11 "Munro and the Ryotwari Settlement in Madras, 1820-27", in R. C. Dutt, The Economic History of India Under Early British Rule.

${ }^{12}$ Amelia (Shipley) Heber, Life of Reginald Heber, D.D., The Lord Bishop of Calcutta by his Widow with Selections, Correspondence, Unpublished Poems, and Private Papers, 1830,Vol -II, p. 413

${ }^{13}$ Claude Markovits (ed.), A History of modern India 1480 -1950, First published 2002, (Wimbledon Publishing Company), Anthem Press,

London, 2006, p.303

${ }^{14}$ Eric Stokes, The English Utilitarians and India, Oxford at Clarendon Press, London, 1959, p. 81

${ }_{15}^{15}$ Neil Charlesworth, British Rule and the Indian Economy, 1800-1914, Macmillan Press Ltd., London, 1982 p.17

${ }^{16}$ Markovits, op. cit., p.303

${ }_{17}$ Gohit, Rohit Kumar, Social and Economic History of Modern India, Murari Lal \& Son Publication, Meerut, 2007. p.138
} 
A Comparative Study Of Zamindari, Raiyatwari And Mahalwari Land Revenue Settlements: The

of land revenue assessment and given the right of internal adjustments. Unfortunately, the system not worked successfully because the settlement officers, who were the carrier of the settlement, turned corrupt and evaded the actual rules and collected the revenue at his own discretion. As a result the system proved miserable to the agricultural classes. This created widespread discontent and finally the Mahalwari System failed to create any extensive effect. ${ }^{18}$

\section{Territorial Acquisition Under Three Settlements}

Permanent Zamindari settlements were made in Bengal, Bihar, Orissa, Banares division of U.P. This settlement was further extended in 1800 to Northern Carnatic (north-eastern part of Madras) and North-Western Provinces (eastern U.P.). It roughly covered 19 percent of total area of British India. The Mahalwari tenure was introduced in major portion of U.P., the Central Provinces, the Punjab (with variations) and the central providences;-while in Oudh villages are placed under taluqdar or middlemen with whom the government deals directly. This system covered nearly 30 percent of the British controlling area. The Raiyatwari settlements were made in major portions of Bombay, Madras and Sindh Province. The principles of this system are also applied to Assam and Burma. A few hilly tracts in Bengal and the coast strip of Orissa have been temporally settled. This system covered roughly 51 percent of the total British Indian territory. ${ }^{19}$ One fifth of the total area of the British India has been permanently settled, viz., about 5/6 of Bengal and Bihar, 1/8 of Assam, 1/10 of U.P., 1/4 of Madras. Of the total land revenue 53 p.c. comes from the first two classes of land, and 47 p.c. from Raiyatwari tracts. ${ }^{20}$

All these major areas were subdivided into many tracts for the better management of land assessment. The three settlements region has been distributed under the in charge of several British officials and native landlord to look after the function of Land Revenue System. For example; initially Bengal territories were distributed among twelve major and many other small Zamindars that not only played the impotent role in land assessment process but also in local administration. ${ }^{21}$ The Madras territories were sub divided into several tracts of Nellore, Trichinoply, Coimbatore, Tanjore, Arcot etc. The Mahalwari settlement region like Central Province was distributed through several divisions of Meerut, Agra, Rohilkhand, Allahabad, Bundelkhand, Varanasi, Gorakhpur, Lucknow, Faizabad, Kumaun etc. ${ }^{22}$

The important of landlord group in land settlement area are: (a) Under Permanent settlement the Zamindars were recognized as proprietors of the soil with rights of free hereditary succession, sale and mortgage, but subject to the loss of their property on failure to the revenue on a fixed date. (B)Settlement limited forever the state demand to a fixed revenue and certain duties or services. (C) System stipulated that the Zamindar should safe-guard the rights of their tenants by granting those pattas or documents stating the area and rent of their respective holdings. (D) The Zamindars were made 'subject to such rules as might be enacted by the government for securing the rights and privileges of the tenants in their respective tenures and for protecting them against undue or oppression'. All abwabs, or cesses levied by the Zamindars in addition to the rent, were abolished. The transit duties and road and ferry tolls were taken over by the government, but the market tools and profits from fisheries, trees and waste land were left entirely to the Zamindars. (E) The talukdars of Bengal were raised to the position of Zamindars and allowed to pay fixed revenue directly to the government. (f) In Madras and Orissa many petty tributary chiefs have been deprived of their ruling powers and reduced to rank of Zamindars, subject to the payment of fixed revenue. Basically the Zamindari system was so-called creator of private property in land. ${ }^{23}$

Under the village settlement (Mahalwari) the revenue is settled for a limited period (30 years in U.P. and 20 years in Punjab and C.P.), with the entire body of villagers who were jointly and separately responsible for the revenue of the whole village. Their head called the Lambardar ${ }^{24}$, sign the agreement with the government to pay the revenue on behalf of the villagers. The assessment of the revenue by the village council is supervised by the settlement officer of the government, and the village maps and records of rights are carefully preserved and brought up to date. The government demand is estimated by a careful calculation of the value of the land, the price of the crops, and the recorded actual produce of the field. In the Mahalwari settlement, the government deals only with the middlemen, whether individuals or group of villagers, who were held responsible for the revenue. Nearly half of the area thus settled is cultivated by these middlemen themselves, and the other half by inferior tenants subject to the middlemen. The government demand was formally 90 p.c. of the net assets, but it

\footnotetext{
${ }^{18}$ R. C Dutt's Letters to Lord Curzon; Dated the $12^{\text {th }}$ May 1900, Remarks on the Land Settlements in Northern-India, Proceeding No. 23, Serial No. 5, p. 29

${ }^{19}$ Bandyopadhayay; op. cit., pp. 82-96

${ }^{20}$ Jadu Nath Sarkar, Economics of British India, Kuntaline Press, M.C Sarkar and Sons, Calcutta,1909, p.100

${ }^{21}$ Islam, S., The Permanent Settlement in Bengal: A Study of Its Operation 1790-1819, Bangla Academy, Dacca (Dhaka), 1979. p.3

${ }^{22}$ P. D Shrimali, Agrarian Structure, Movements and Peasant Organization in Uttar.Pradesh, V.V. Giri National Academy, Manak Publication, New Delhi, 2004, pp. 33-35

${ }^{23}$ Bandopadhayay; op. cit., p. 84

${ }^{24}$ See For Detail: Maine, H. S., Village Community in the East and West, B. R Publishing Corporation, New Delhi, First Published 1913, Reprinted 1985.
} 
A Comparative Study Of Zamindari, Raiyatwari And Mahalwari Land Revenue Settlements: The

was now been reduced to 50 p.c., or even less, except in Bombay, where there was no limit of to the maximum. The net asset is taken to be the economic rent which the actual cultivators pays to the superior proprietors, where there is subletting. In other places, the net assets is arrived at by deducting from the assume price of the crops the approximate cost of production, and little extra for his luxurious. In the province of Oudh, the government settled the revenue of a group of villages with a Talukdar or chief. These Talukdars differ from the Zamindars of Bengal in two respects: (1) the settlement with the former is temporary, and they have no absolute right over their estates such as the Bengal Zamindars possess. ${ }^{25}$

Under the Raiyatwari settlement the government deals directly with the cultivators and recognizes no middlemen. Each village is carefully surveyed, and every cultivator's holding or plot of land in it was marked and separately numbered. Village maps with accurate boundary lines, classification of the soil, and the names of the occupants, are carefully compiled and preserved, and the revenue was assessed on each occupant. This right of occupancy can be inherited and transferred by the peasants; hence there was some amount of sub-letting even in the Raiyatwari provinces. In other respects the method of assessment was the same as in the Mahalwari settlement. ${ }^{26}$

The Zamindari and Raiyatwari areas differed in the pattern of their subsequent development. One important determinant was investment. In Zamindari area, the government left the responsibility of making investment to the Zamindars. In Raiyatwari areas, they implicitly or explicitly assumed this responsibility. Perhaps there was an element of calculation too behind this discussion. Taxes being fixed forever in the Zamindari areas, the government could not hope to recover returns to increased asset value of the land in the form of taxes. In Ryotwari the road remained open. This was one of the reasons, but perhaps not the only one, why irrigation development occurred to a greater extent in the Ryotwari areas. Further, revenue farming had already weakened the official information-gathering system in the villages on the eve of the Permanent settlement. Consequently, Zamindari areas continued for long to remain statistical back holes. ${ }^{27}$

Baden Powell, one of the authorities on land revenue system in British India, summarized the several interests in land under different system of tenures. In the situation of state landlordism, there was only one interest in land was categorized into two, the government and the Raiyats. In Zamindari it was three, the government, the Zamindars, and the actual cultivating holders. In Mahalwari system the interest in land was categorizes into four, the government, the landlord, tenant holders and actual cultivating holders. ${ }^{28}$ These three systems underwent lot of conversion during the course of years and this resulted the intermixing of feature in fact tended towards Zamindari system. Evils of Zamindari system and absentee landlordism percolated all the tenurial system in India. Subletting and rack-renting became a common trait even in the Raiyatwari areas. The Mahalwari system acquired the traits of Zamindari system in Madhya Pradesh and U. P. where the government laid stress on joint responsibility of the village for land revenue assessment. ${ }^{29}$

Under permanent settlement the protection of right of the cultivators for which government had stipulated with the Zamindars in 1793, was long neglected, and has been secured by later legislation. The occupancy tenants of Bengal and the cultivating village owner of Bihar, now practically occupy the position of the peasant-proprietors of Europe, and are subject to the magic of property. The first named class enjoys the entire fruits of their labour and capital and always a certain position at least, in practice the whole, of the unearned increment. They have every interest in improving their lands, and agriculture flourishing under them. Where illegal cesses are still levied by the Zamindars, it is due to the corruption or weakness of the police, but cannot be necessary consequences of the Permanent Settlement. Though the settlement was pro-Zamindar, they too hard to face a number of difficulties. As Daniel Thorner had argued, creation of private property in land was a misnomer, as the absolute ownership was retained by imperial authority ${ }^{30}$ The vigilant care of Magistrates is rendering such unauthorized extortion less frequent, in the same way as it is putting down dacoities. Where a royt is non-occupancy he cannot spent his capital on improvements, and industry is discouraged. But the Zamindari system is theoretically favorable to agricultural improvement at the cost of the Zamindar, because he is the permanent owner can recover his outlay from the land. Moreover Zamindari estate being large in area, if a Zamindar betakes himself to farming, he can derive all the advantages of production on a large scale, which is impossible in the small plots of the Mahalwari and Raiyatwari areas.

The permanent settlement by creating a rich and leisured class has fostered the accumulation of capital, and large industries may be rendered possible in eastern India by the financial banking of Zamindars, and acts as a body of middleman between the state and cultivator, who have identified themselves with British rule, and have always given loyal help in the cause of good administration. ${ }^{31}$ Other hand under the Mahalwari and

\footnotetext{
${ }^{25}$ Bandopadhayay, S., op. cit., pp. 92-96

${ }^{26}$ Sarkar, J., op. cit., pp.100-105

${ }^{27}$ Tirthankar Roy, 'The Economic History of India; 1857-1947, Oxford University Press, 2006, p. 58

${ }^{28}$ See for more: Baden Powell, B. H., The Land System of British India, Oxford at Clarendon Press, A Set of three Volumes, London, 1892.

${ }^{29}$ Gohit; op. cit, p.138

${ }^{30}$ D. N Dhanagre, Peasant movements in India, 1920-1950, Oxford university press, New Delhi, 1983 (cited in)

${ }^{31}$ Cotton; op. cit., p.79
} 
A Comparative Study Of Zamindari, Raiyatwari And Mahalwari Land Revenue Settlements: The

Ryotwari settlement, state is a landowner with all the advantages of a monopolist. The competition among landlords for tenants which Ricardo's theory of rent ${ }^{32}$ presupposes, is wanting here, because there is only one landlord that is the government. The Raiyat was at the mercy of the state-proprietors and the rent here being a monopoly rent must theoretically be an element in the price of agricultural produce. ${ }^{33}$ The government lets the land only in very small plots, averaging 5 acres each, so that agriculture on a large scale is impossible, even when a capitalist is ready to undertake it. The chance of enhancement of the revenue at every periodical settlement discourages industry and the investment of the Raiyaty's capital in land. The Raiyat, having no right of property in his holding, has no inducement to become a developed agriculturalist. Capital cannot accumulate from the pursuit of agriculture, because the bare subsistence is left to the Raiyats, and the surplus produce of the land is 'swept into the coffer of the state '. A revenue system administrated by petty government servants according to fixed rules is sure to be inelastic, and the Raiyats are likely to be ruined by the strict enforcement of the state dues in the years of famine, unless remission of revenue is promptly ordered by the head of the government.

Before we briefly consider each variety of settlement by itself, we will take notice of some features which all verities of modern revenue-settlement have in common. ${ }^{34}$ A complete survey of the land, involving a preliminary demarcation of the necessary boundary lines is essential. There must be a correct list of the revenue payers and their holdings, and a schedule accounting every plot and land in each village. Lastly there must be a valuation of the land, the ascertainment of revenue rates, the totaling up the adjusting of them to give the sum payable by the estate or holding.

The permanent settlement which was the first system to be tried, was the only one made without any demarcation of boundaries. It will be found that the settlements with great landlords in Bengal and Madras come under the first'; and those with Oudh Talukdars under the second: and all the settlement system of the Agra, Central Province, Punjab, etc., as well as the system called Raiyatwari, is all 'temporary' and have the demarcation, survey, and records of rights carried out. ${ }^{35}$

The Middleman- in writing relating to the land settlement we so often find reference to the 'middleman' proprietors. In Permanent and Mahalwari settlement, there was some kind of middleman between the actual cultivator and the Government; and this middleman is more or less fully, the proprietors and holds the settlement. In Raiyatwari system, there was ordinarily no such pension; the pays direct to the state, the revenue assessed on the particular fields he holds. (Munro strongly urge for the new departure - the Raiyatwari method with no middleman). ${ }^{36}$

In the Zamindari settlement the landlord has a legal proprietary title, but also a fixed responsibility. He is bound to the land and to the payment of revenue on it for the whole term of settlement; he cannot at his option relinquish the estate. Hence the early settlements especially, he always signed an agreement for the term; and there is in fact a contract between him and the state. In Raiyatwari system the occupant is held by no lease and signs no agreement. He cannot indeed have the revenue rate assessed on his holding raised during the period of settlement; but he can at the close of any year or before the next cultivating season begins, relinquish his holding and so free himself from responsibility whenever he pleases. ${ }^{37}$

In the permanent settlement area the assessment was on the whole estate, but it was for a period of years only. If the villages in the estate had preserved their constitution and were not bodies of contract tenants, a "sub-settlement" would be made, which fixed what the village was to pay to the landlord; only that in that case it would be fixed at a higher figure to allow for the overlord's profit. In case where the talukdari or double tenure was found, the villages held the settlement direct, but the talukdari allowance was proved by for making the assessment so much higher as to include the amount. This was payable through the treasure and was not collected by the overlord. ${ }^{38}$ Under Mahalwari settlement the village itself was landlord, the section on village tenures will have made the form of ownership intelligibly; so that it need here only to briefly stated that the entire body was settled with a jointly and severally responsible unit; and that for each village or each patti or section, a sharer of standing and respectability undertook the primary liability and signed the revenue agreement on behalf of the whole body. Such a person was called 'lambardar'. The burden of the revenue is distributed among the co-sharers according to the principle of sharing and constitution of the estate. This process called the bachh. In the case of the mahal settlement the assessment are based on more or less directly, on the actual rental value of the lands in the village unlike permanent settlement.

\footnotetext{
${ }^{32}$ For Detail see: Ricardo, David. 'Principles of Political Economy and Taxation' (1817)

${ }^{33}$ Eric stokes, 'The Land Revenue System of the North Western Provinces and Bombay Deccan 1830-80: Ideology and Official Mind', in Burton Stein (ed.), The Making of Agrarian Policy in India, 1770- 1900, Oxford University Press, Delhi, 1992.

${ }_{34}^{34}$ B .H Baden Powell; Administration of Land Revenue and Tenure in British India, Ess Ess Publication, New Delhi, 1907, pp.147-8.

${ }^{35}$ Ibid., p. 149; Also see: B .H Baden Powell , A Short Account of Land Revenue and its Administration in British India; With a Sketch of the Land Tenure, Clarendon Press, London, 1894.

${ }^{36}$ Powell, op.cit., p. 150

${ }^{37}$ Cotton; op. cit., p. 81

${ }^{38}$ Sumit Sarkar; Modern India, 1885-1947, Macmillan India Ltd., New Delhi, 1983, p.33-35
} 
A Comparative Study Of Zamindari, Raiyatwari And Mahalwari Land Revenue Settlements: The

Munro's Raiyatwari settlement commences with an accurate survey and a methodology of dealing with separate holding, and of laying a rate on the land rather than arranging a payment for the individual. The Raiyatwari system does not profess to determine rights in the way that the Mahalwari system does; dealing with the actual occupant of each field, there is no need to do more than value and assess the field correctly. Like village settlement area the Raiyatwari region properly classified the land and soil and assessed the rent correctly. The basis of the assessment is in theory at any rate that is not to exceed 50 percent of the net produce. To find out this the gross produce is first ascertained and valued at average price, the costs of cultivation etc. are than deducted, half the balance is taken as the revenue. In this context the Bombay settlement unlike Madras possesses a complete revenue code (Bombay Act V of 1879) which include4 all power of survey, assessment, and other matters, connected with settlement. ${ }^{39}$

Methods of collection of land revenue in the three distinguished settlements were different. In permanent settlement area naturally the collector collected the revenue from the Zamindar on a fixed date. The Zamindar were bound to submit the fixed amount on due date punctually under threat of the immediate sale of the estate. In Eastern India, the permanent settlement gave proprietary rights to the middle tire, the formally powerful tax collectors, in exchange for a sum of money that was fixed in perpetuity. ${ }^{40}$ In Madras there is some difference: the Act (II of 1864) says the recovery shall be according to the terms of the title deed. The land revenue Acts of the provinces where village-estate settlements prevail, have a different procedure for the recovery of arrears of the land revenue and other public dues that are provided by law to be recoverable as if they were arrears of land revenue. Briefly, instead of sale being the first and ordinary procedure, it is only adopted as the last report. There were a series of measures, beginning with a simple notice of demand; and only if the others fail can the sale of the estate be ordered. The revenue in village settlement is made payable by certain installments, and if these are not paid up in full at due date, the responsible party became a defaulter. In Mahalwari region basically the headman are primarily and personally liable as defaulter for the land revenue arrears of their village or section of a village (Patti). These headmen were regulated by the government official called Tahsildar. In Raiyatwari provinces, in each year before the collections are closed, an account is prepared, village by village by the village officers and under supervision of the Assistant collector of the land actually held, and the correct total dues for the year. This necessitated by the fact that the Rayiyats may have relinquished some of his land, or taken up new field on application. In Raiyatwari provinces also there were various items of revenue account to be gone into; certain remissions which was always allowed for spoiled crops, and certain adjustment with reference to water rate, this process known as Jamabandi. As regard the actual process of recovery in arrears, in Madras, the law provides for the attachment and sale of movable and immovable property, and the imprisonment of the defaulter. Immovable property is not sold without first issuing a write of demand seeing whether the defaulter can make some arrangement for payment. The property moreover, need not be sold outright, but may be taken under management. As to the conditions under which personal arrest are allowed. ${ }^{41}$

\section{Resemblance}

Similarities among three settlements behind the apparent differences, the Raiyatwari and the Zamindari system shared certain fundamental similarities. In both cases, the British had favored certain categories of right holders to the detriments of the others by conferring on them full and undivided ownership of the land. Other hand in Mahalwari region the local chiefs (rajahs, Zamindars, talukdars), being of ancient stock or firmly established were conformed as owner. But most often, it transpired that the mastery over village cultivated lands, in these regions, traditionally belonged to the undivided community of farmers, in general presented by the village chief. Here, as elsewhere, the group of powerful individuals who became full-fledged proprietors did not include all the cultivators. It consist of a peasant elite like intermediaries of others settlement area that employed agricultural labour, and whose land were often cultivated by tenants. The Raiyat of South India was dominant peasants with whom, in each village, the agents of the company had deemed it expedient to negotiate and with whom other categories of subordinate right holders subsisted. As the customary organization of land rights often varied considerably from one region to another, the standard term of 'Raiyatwari system' in effect embraced passably different configuration. In these systems, the spirit of the law tended towards the institution of ownership in the modern sense of the word, and with it, of a mode of agrarian relations whose logic was contractual and commercial, even if in practice, the evolution of mentalities towards this direction proved to be very slow. The very dissimilar land stratification that both the system seemed to announce soon tended to find a common meeting ground. Owing to the practice of the judicial sale of the properties of defaulting tax payers, on the one hand the domains of Zamindar were divided into medium and small properties, and on the other, Raiyats became medium or big owners by successive acquisitions. The colonial administration had come through the phase of familiarizing itself with local realities and simple adopted the models elaborated in the course of the

\footnotetext{
${ }^{39}$ Ibid, p. 200-201

${ }^{40}$ Tirthankar Roy; The Economic History of India (1857 -1947), Oxford University Press, New Delhi, 2006, p. 48

${ }^{41}$ Baden Powell; Op. cit, p. 238-244
} 
conquest of the diverse regional contexts, with the two fold objective of ensuring sufficient tax revenues and of gaining the support of the rural elites. Under these the system, the place of the land in social life remained unchanged. Enjoying a preponderant right on land, in the Indian society, says at the same time benefiting from the revenue that this land produced and exercising power over dependents that drew from it the whole or part of their subsistence. The relation to the land was, as it were, encompassed in social relations. The introduction of ownership- and of a judicial conception of agrarian relation on a contractual basis- initially only reinforced in the villages the local power of the already dominant individuals or groups, who were to became the first users or the principle beneficiaries of the colonial legislative and legal machinery. The seeds of modern conception of the relation between owners and tenants or employees were showed in the minds, but they would produce a perceptible effect in mentalities only in the long run. ${ }^{42}$

\section{Position of Tenants:}

Mr. Dutt in his latter to Lord Curzon pointed out the condition and actual position of tenants in these settlement areas. He asserted the Bengal peasants were more prosperous, more resource full and better able to help themselves in years of bad harvests than cultivators in any other part of India. Therefore apparently means because of the permanent settlement coupled with the restrictions on enhancement of rent by the Zamindars. ${ }^{43}$ The Zamindar settlement turned the entire peasantry formally into the Zamindars' tenants, liable for rent payment. The principle problem with the position of the tenants in the early years was that the government left open the question of whether or not the Zamindar could raise rent. And in this game, the dominant and large tenants were often bribed into collusion or a silent acceptance so that the weaker tenants had no option but to pay. ${ }^{44}$ Ratna Lekha Ray argued that taking advantage of the Zamindars' own distance from land and unstable economic condition, wealthy peasants with superior tenancy rights extended their landholdings, so much so that they put limit. ${ }^{45}$

Raiyatwari system weakened the middle tier and strengthened peasant rights. However, the Raiyat in question differed in character between regions. One particular variation of this principle occurred in parts of Northern India, where joints peasant rights were strengthened. In the upper Doab and Rohilkhand, talukdars were suppressed and the 'village republics' were recognized as the proprietary body. The joint landlords of village land were collectively responsible for the revenue. Agriculture were unsecured and population too thin here to generate large rents. Therefore joint rights cemented by clan or kingship were possible. By and large, in southern and western India, 'mirasdars' were granted proprietary rights. The Mirasdars being technically holders of shares in village land, the system and the joint-landlord type of assessment could become in many cases indistinct. The political prelude to this system in the south was the suppression of poligars in 1799-1800. They were partly like the northern Zamindars. A few of them did become Zamindars under British rule. ${ }^{46}$

In Ryotwari area the proprietary right is perfect, and as long he pays affixed assessment on his land, he can be ousted by no one; there is no principle of Raiyatwari management more fixed or better known than this, and the government denied that any right can be stronger. It is thus abundantly clear that the distinguishing feature of Raiyatwari is the limitation is perpetuity of the demand of the state on the land, the Raiyat have thus all the advantages of the Zamindari tenure, while the state has a valuable reserve of waste land whence, as cultivation extends, its resource will be augmented so as to meet the increasing demand on its finances which the progress of the country will entitle. ${ }^{47}$

In deciding who gained and who lost through this process, we need to note first of all that the answered varied by regions because the precise mix between colonial ideologies and practice varied too. In Zamindari area the older elite on the whole gained. But some of this gained faded away as the nineteenth century wore on and groups of rich farmers consolidated their economic power by participating in the market, something that the Zamindars never could do. The general character of land transfers in colonial India was not only from the poor to the rich, but contained a significant element of rich-to-poor as well. In the process, asset inequality remained broadly unchanged. ${ }^{48}$

\section{Magnitude of assessments:}

In the Zamindari settlements, the land tax was fixed forever. In the Raiyatwari areas, the land tax was fixed sublet to periodic revision like northern India. It generally believed that the first round of settlements set

\footnotetext{
${ }^{42}$ Markovits; op. cit., p.300-305

${ }^{43}$ From the private secretary to his Excellency the Viceroy and Governor General in India, Dated $14^{\text {th }}$ May 1900 , transfer for disposal a memorial from Mr. R. C., Dutt regarding land settlement in Bengal, Prof. No. 22, Serial No. 4, p. 21

${ }^{44}$ Roy, T., op. cit., ,p. 49

${ }^{45}$ Ratna Lekha Ray, Change in Bengal Agrarian Society c.1760-1850, Delhi: Manohar, 1979 and Rajat Datta, 'Agricultural Production, Social Participation and Domination in late Eighteenth Century Bengal: Towards an Alternative Explanation', Journal of Peasant Studies, 17(1), 1989, pp.68-113

${ }^{46}$ Roy; op. cit., p. $50-51$

${ }^{47}$ Dutt's letter to Curzon, Dated $20^{\text {th }}$ February 1900, op. cit., Profceeding No. 20, Serial No. 2, p. 2

${ }^{48}$ Dharma Kumar, 'Landownership and Inequality in Madras Presidency', IESHR, 12 (2), 1975, pp. 229-73
} 
A Comparative Study Of Zamindari, Raiyatwari And Mahalwari Land Revenue Settlements: The

taxes too high, possible causing peasant distress and an agrarian depression. The idea of an agrarian depression sometime in the second quarter of the nineteenth century has been articulated in regional histories of the Bombay-Deccan and Madras. ${ }^{49}$ Therefore second round of settlements in the 1840s moderated the tax burden considerably.

The institutional reforms were a curious mix of old practices and new ideas. Many element and custom were suppressed. Chief among these was the authority of local officials to punish the defaulting tax collectors or peasant. Suppression of this right made it possible for land to change hands faster and more easily when default occurred. By the permanent settlement and the Raiyatwari settlement to follow in Madras and Bombay, the new regime of the East India Company made public sale of ownership rights mandatory when tax default occurred. The revenue officials after 1816 combined in themselves both revenue collection and police duties in the countryside. This enhancement of power inevitably resulted in coercion, bribery and corruption by the subordinate officials of the collectors who were reveled in abundant and gory details in Madras Torture Commission Report in $1855 .{ }^{50}$

The people of Bengal and of northern India gradually obtained some relief from the heavy land assessment of the early years of the British rule. In Bengal the assessment was made permanent; and it has not been raised with the extension of cultivation, it now bears a ratio of about 35 percent, on the rental. In northern India the assessment was not made permanent, but it was reduced to slightly over 50 percent, including all 'cesses', in 1885. But new 'cesses' were added; calculations were made, not on the current, but on the prospective rental, until the tax rose to close upon 60 percent on the rental. The first fifteen years of the permanent settlement saw a burst of distress- driven auction of Zamindari estate in greater Bengal induced by sharply raised effective revenue collection, a series of minor or large agrarian crisis, and the "proverbial incompetence' of Zamindars in managing their estates ${ }^{51} \mathrm{We}$ need to remember that many among these groups were never cultivators themselves and were unable to meet the increased demand by improving their cultivation practices. The distress sale declined thereafter as the rental value of and exceeded the revenue burden that had been fixed in money terms. The auction sales tended to large estates into smaller lots. Those who brought these lots included adventure $s$ and outsider, who were equally rapacious towards the peasants as some $f$ the Zamindars. The peasants mockingly called these new people 'lotdas', or owners of lots. The frequent sale of Zamindari estates caused poverty highly. Between 1794 and 1807 land yielding about $41 \%$ of the revenue in Bengal and Bihar was sold out in auction; in Orissa between 1804 and 1818 about 51\% of the original Zamindars were wiped off. ${ }^{52}$

In Madras and Bombay things are worse. There the land tax is paid generally by the cultivators of the soil, there being, in most parts of those provinces, no intervening landlords. The British government declared its intention in 1864 of releasing as land tax about one half of the economic rent. But what the British government does take as land tax at the present day sometimes approximates to the whole of the economic rent, leaving the cultivators little beyond the wages of their labour and the profit of their agricultural stock. The land tax is revised once every thirty years; the cultivators does not know on what grounds it is enhanced; he has to submit to each renewed assessment, or to his ancestral fields and perish. This uncertainty of land tax paralyses agriculture, prevents savings, and keeps the tiller of the soil in a state of poverty and indebtedness. ${ }^{53}$

After a period of inactivity, the government of east India Company fixed the rent charged by the Zamindars to their tenants. Bitter complaints about Zamindari exploitation of cultivators continued, however. A series of tenancy Acts (1859-1928) recognized and strengthen the occupancy rights of the tenants settled on a land for many generations. This is a process that later writers called 'sub-infeudation' ${ }^{54} \mathrm{Mr}$. Dutt asked for the protection as possible under the land system of each province against frequent reassessments and undue enhancements be granted to the cultivators all over India. This precisely represents the policy pursued by the government of India. During the Viceroyalty of Lord Ripon and subsequently Viceroyalties several measures followed in the context on the relations of land lord and tenant. As a result the Bengal, North-Western provinces and Oudh, the Punjab and Central Provinces ere all equipped with tenancy Acts, the main object of which was to strengthen the position of the actual cultivators and afford him that protection which Mr. Dutt desires to see established. ${ }^{55}$

\footnotetext{
${ }^{49}$ Readings: Fukazawa, H., 'Agrarian Relations: Western India', CEHI 2, pp.177-206. An older discussion of the theme can be found in P.J. Thomson and Natarajan, B., 'Economic Depression in the Madras Presidency, 1825-54', HER, vol-7(1), 1936, pp. 67-75

${ }^{50}$ David Arnold, Police Power and Colonial Rule in Madras, 1859-1947, Oxford University Press, New Delhi, 1986, p. 20

${ }^{51}$ S. Chaudhari, 'Agrarian Relation: Eastern India', in Kumar (ed.), op. cit., p. 94.

${ }^{52}$ B. B Chaudhari, The Land Market in Eastern India, 1793-1940, Indian Economic and Social Review, New Delhi, 1975, 12 (1):1-42, p.56

${ }^{53}$ Dutt, Vol -I, op. cit., p. xxiv

${ }^{54}$ C. Bates; Regional Dependence and Rural Development in Central India: the Pivotal role of Migrant Labour, in David Ludden (ed.), Agricultural Production in Indian History, Oxford University Press, New Delhi, 1994, p. 324

${ }^{55}$ From the private secretary to his Excellency the Viceroy and Governor General in India, Dated $14^{\text {th }}$ May 1900 , transfer for disposal a memorial from Mr. R. C., Dutt regarding land settlement in Bengal. Prof. No. 22 and Serial No. 4, p. 26
} 
A Comparative Study Of Zamindari, Raiyatwari And Mahalwari Land Revenue Settlements: The

In all the British territories under the Raiyatwari or Mahalwari system, codified methods and specialized administration gradually put in place for the registration of land and for the registration of land rights, of rents and charges. The same work had to be under the Zamindari system, not for the assessment of tax but for the protection of rights of tenants and for the requirements of justice. As earlier in the countries of permanent settlement, land revenue in these provinces was generally fixed too high in order to meet the tax demand of the East India Company, and its integral and punctual payment was enforced with inflexible rigor. There followed many regions, in the course of the first few decades of the nineteenth century, an important trend of alienations, as the farmers, especially in the times of crisis, were forced to sell due to excessive indebtedness, or their land were confiscated and sold by auction on the ground of a tax default. ${ }^{56}$

In practice the British land revenue policies may have been most disruptive, not through their adjudication of land tenure, but at the simple level of financial demands they made. Many of the early British settlements- notably the 'permanent settlement' of Bengal of 1793 and Pringle's in Bombay during the 1820s and the 1830s were marked by considerable over assessment. The in their zeal for funds, often accepted the most optimistic inherited estimates of agriculture's capacity to pay, claims which were excessive in the depressed conditions of the first third of the nineteenth century. Finally it terms of political consequences, Stokes's recent work has undermined the notion of the mutiny conflagration of 1857-8 as a simple outburst by the victims of British agrarian policy, particularly in Mahalwari regions. On the other side several peasant uprising occurred in nineteenth century both in Zamindari and Raiyatwari regions, and a number of grim famines appeared in these settlement area. ${ }^{57}$

The magnitude of land tax in 1851-52 shows the exploitative character of imperial power in India. During this period the amount of land revenue was very high in every province. The total net revenues of India in 1851-52 were 19, 927.039 pound. A comparative index of Land Tax in India: ${ }^{58}$

Bengal oscillated in last four years from 3,500,000 to 3,560,000 pound.

North West oscillated in last four years from $4,870,000$ to $4,900.000$ pound

Madras oscillated in last four years from 3,640,000 to 3,470,000 pound.

Bombay oscillated in last four years from 2,240,000 to 2,300,000 pound.

Gross Revenue in 1852-52:

\begin{tabular}{|c|c|c|c|c|}
\hline & \\
\hline & $\begin{array}{l}\text { ngal } \\
\text { dras........................................... } \\
\text { mbay }\end{array}$ \\
\hline
\end{tabular}

Sum total revenue from these three provinces was $19,800.000$ pound. ${ }^{59}$

In concluding paragraph I would like to draw the final assessment of aftermath of various land settlements in together. The process of "Drain of Wealth", that started by the advent of the British colonial power in India, hastened through accumulating primary capital based on landed revenue. The important channel of draining wealth from India to England was trade, but the main source of moving wealth was land tax. This is the British government which first realized to keep up a constant relation with the native people in regard to became a financially healthy ruler of India. As a result they first concentrated into economic reforms in India specially the land reforms missions. Not only the government officials but also the English people of home engaged themselves to launch several land settlement, in modified shape equipped with statistical methods under the influences of modern liberal and economic thoughts. The British East India Company was the pioneer of three major land settlements in India, viz., Permanent, Raiyatwari and, Mahalwari, were introduced in various regions of India on the basis of contemporary circumstances and colonial requirements. Basically these were the modern way of extracting maximum revenues from the peasants and, an absolute plan to plunder Indian resources constantly. The land tax was the major source of revenue for the British Government; amounting in $1858-59$, to Rs 18.12 corers or 50.3 percent of total its revenues. ${ }^{60}$ It is true that the British land reform programs no-doubt provided a great zenith to the process of agrarian transformation from medieval to modern time and, brought several changes both in agricultural methods and its patterns and, revolutionaries several rural and urban areas. But in other sense these process had been indulged the process of sever stratification of Indian society on the basis of occupational position and, paved an era of future secondary contradiction between the rich and poor in Indian political, economical, and social history, along with impoverishing a considerable portion of Indian mass (agricultural population), leading towards human inequality.

\footnotetext{
${ }^{56}$ Sarkar; op. cit., pp. 33-36

${ }^{57}$ Ibid., pp.19-20

${ }^{58}$ For Detail see: Charlesworth, Neil, British Rule and the Indian Economy 1800-1914, The Macmillan Press LTD, London, 1982

${ }^{59}$ Karl Marx, on Sir Charles Wood's East India Reforms, New York Daily Tribune, no.3801. June 22, 1853, in Marx on Colonialism.

${ }^{60}$ Irfan Habib; Indian Economy, 1858-1914, People's Series, No. 28, Tulika Books, 2006, p. 61
} 


\section{Primary:}

\section{References}

[1] From the private secretary to his Excellency the Viceroy and Governor General in India, Dated $14^{\text {th }}$ May 1900 , Transfer for Disposal, A Memorial from Mr. R. C., Dutt Regarding Land Settlement, in Bengal Proceedings No. 22 , Serial No. 4.

[2] R. C. Dutt's Letter to Lord Curzon on the subject of Land Revenue Settlements in Madras, dated 20 ${ }^{\text {th }}$ February 1900 , Proceedings No. 20, Serial No. 2

[3] Amelia (Shipley) Heber, Life of Reginald Heber, D.D., The Lord Bishop of Calcutta by his Widow with Selections, Correspondence, Unpublished Poems, and Private Papers, 1830, Vol -II

[4] R. C Dutt's Letters to Lord Curzon; Dated the $12^{\text {th }}$ May 1900, Remarks on the Land Settlements in Northern-India, Proceeding No. 23, Serial No. 5

[5] From the private secretary to his Excellency the Viceroy and Governor General in India, Dated $14^{\text {th }}$ May 1900 , transfer for disposal a memorial from Mr. R. C., Dutt regarding land settlement in Bengal, Prof. No. 22, Serial No. 4, p. 21

[6] Dutt's letter to Curzon, Dated $20^{\text {th }}$ February 1900, op. cit., Profceeding No. 20, Serial No. 2

[7] From the private secretary to his Excellency the Viceroy and Governor General in India, Dated $14^{\text {th }}$ May 1900 , transfer for disposal a memorial from Mr. R. C., Dutt regarding land settlement in Bengal. Prof. No. 22 and Serial No. 4,

[8] Regulation IX of 1833, R. M. Bird, in Revenue Law Report, North Western Provinces, 1867

\section{Secondary:}

[1] Karl Marx, The Future Result of British in India, New York Daily Tribune, June 1853. No.3840, in Marx and Angles; On Colonialism, Foreign Language Publishing House, Moscow, 1960

[2] A. R Desai, Social Background of Indian Nationalism, Popular Prakashan, Bombay, 1948

[3] Sekhar Bandyopadhayay; From Plassey to Partition: A History of Modern India, Orient Longman, New Delhi, 2004

[4] Romesh C. Dutt, The Economic History of India: In the Victorian Age, Vol -II, Ministry of information and Broadcasting, govt. of India, New Delhi, 1963

[5] Irfan Habib; Essays in Indian History, Tulika Books, New Delhi, 1995

[6] Henry Cotton; India in Transition, B. R. Publishing Corporation, Delhi, 1885

[7] Dutt, R. C., The Economic History of India: Under Early British Rule, Vol. II, Routledge \& Kegan Ltd., London, 1882, First Indian Edition 1960, Publication division, Ministry of Information and Broadcasting, Government of India Press, New Delhi, Reprinted 1963

[8] "Munro and the Ryotwari Settlement in Madras, 1820-27", in R. C. Dutt, The Economic History of India Under Early British Rule.

[9] Claude Markovits (ed.), A History of modern India 1480 -1950, First published 2002, (Wimbledon Publishing Company), Anthem Press, London, 2006,

[10] Eric Stokes, The English Utilitarians and India, Oxford at Clarendon Press, London, 1959

[11] Neil Charlesworth, British Rule and the Indian Economy, 1800-1914, Macmillan Press Ltd., London, 1982

[12] Gohit, Rohit Kumar, Social and Economic History of Modern India, Murari Lal \& Son Publication, Meerut, 2007.

[13] Jadu Nath Sarkar, Economics of British India, Kuntaline Press, M.C Sarkar and Sons, Calcutta,1909

[14] Islam, S., The Permanent Settlement in Bengal: A Study of Its Operation 1790-1819, Bangla Academy, Dacca (Dhaka), 1979.

[15] P. D Shrimali, Agrarian Structure, Movements and Peasant Organization in Uttar.Pradesh, V.V. Giri National Academy, Manak Publication, New Delhi, 2004

[16] Maine, H. S., Village Community in the East and West, B. R Publishing Corporation, New Delhi, First Published 1913, Reprinted 1985.

[17] Tirthankar Roy, 'The Economic History of India; 1857-1947, Oxford University Press, New Delhi, 2006

[18] Baden Powell, B. H., The Land System of British India, Oxford at Clarendon Press, A Set of three Volumes, London, 1892

[19] D. N Dhanagre, Peasant movements in India, 1920-1950, Oxford University press, New Delhi, 1983

[20] Ricardo, David. 'Principles of Political Economy and Taxation', John Murry, London, 1817

[21] Eric stokes, 'The Land Revenue System of the North Western Provinces and Bombay Deccan 1830-80: Ideology and Official Mind', in Burton Stein (ed.), The Making of Agrarian Policy in India, 1770- 1900, Oxford University Press, Delhi, 1992.

[22] B .H Baden Powell; Administration of Land Revenue and Tenure in British India, Ess Ess Publication, New Delhi, 1907

[23] B .H Baden Powell , A Short Account of Land Revenue and its Administration in British India; With a Sketch of the Land Tenure, Clarendon Press, London, 1894.

[24] Sumit Sarkar; Modern India, 1885-1947, Macmillan India Ltd., New Delhi, 1983

[25] Ratna Lekha Ray, Change in Bengal Agrarian Society c.1760-1850, Delhi: Manohar, 1979 and Rajat Datta, 'Agricultural Production, Social Participation and Domination in late Eighteenth Century Bengal: Towards an Alternative Explanation', Journal of Peasant Studies, 17(1), 1989

[26] Dharma Kumar, 'Landownership and Inequality in Madras Presidency', IESHR, 12 (2), 1975

[27] Readings: Fukazawa, H., 'Agrarian Relations: Western India', CEHI 2, pp.177-206. An older discussion of the theme can be found in P.J. Thomson and Natarajan, B., 'Economic Depression in the Madras Presidency, 1825-54', HER, vol-7(1), 1936

[28] David Arnold, Police Power and Colonial Rule in Madras, 1859-1947, Oxford University Press, New Delhi, 1986

[29] B. B Chaudhari, The Land Market in Eastern India, 1793-1940, Indian Economic and Social Review, New Delhi, 1975

[30] C. Bates; Regional Dependence and Rural Development in Central India: the Pivotal role of Migrant Labour, in David Ludden (ed.), Agricultural Production in Indian History, Oxford University Press, New Delhi, 1994

[31] Charlesworth, Neil, British Rule and the Indian Economy 1800-1914, The Macmillan Press LTD, London, 1982.

[32] Karl Marx, on Sir Charles Wood's East India Reforms, New York Daily Tribune, no.3801. June 22, 1853, in Marx on Colonialism.

[33] Irfan Habib; Indian Economy, 1858-1914, People's Series, No. 28, Tulika Books, 2006 